\title{
EVALUATION OF HEMOSTASIS DISORDERS AND ANTICARDIOLIPIN ANTIBODY IN PATIENTS WITH SEVERE LEPTOSPIROSIS
}

Elizabeth De Francesco DAHER(1,2), Francisco Holanda OLIVEIRA NETO(1) \& Susana Marcela Pineida RAMIREZ(1)

\begin{abstract}
SUMMARY
A prospective study was designed to evaluate disorders of hemostasis and levels of anticardiolipin antibodies (ACL) in 30 patients with severe leptospirosis and acute renal failure (ARF) (ARF was defined as serum creatinine $\geq 1.5 \mathrm{mg} / \mathrm{dL}$ ). The patients had been admitted to the Walter Cantídio University Hospital, São José Infectious Diseases Hospital and General Hospital of Fortaleza, Ceará, from August 1999 to July 2001. They all were male, with a mean age of $32 \pm 14$ years and with clinical and laboratory diagnoses of ARF leptospirosis. The time elapsed between onset of symptoms and the first hemorrhagic manifestation was $9 \pm 4$ days. Bleeding was observed in $86 \%$ of the patients. Laboratory tests showed significantly high levels of urea (181 $\pm 95 \mathrm{mg} / \mathrm{dl})$, fibrinogen, $(515 \pm$ $220 \mathrm{mg} / \mathrm{dl})$, prothrombin time $(13.3 \pm 0.9$ seconds $)$ and low platelet counts $\left(69 \pm 65 \times 10^{3} / \mathrm{mm}^{3}\right)$ on admission. There was no elevation in activated partial thromboplastin time or thrombin time. Levels of IgM and IgG ACL concentrations were significantly increased (p $<0.05)$ in leptospirosis patients when compared to control patients $(28.5 \pm 32.4 \mathrm{vs} .11 .5 \pm 7.9 \mathrm{MPL} \mathrm{U} / \mathrm{ml}$ and $36.7 \pm 36.1 \mathrm{vs}$. $6.5 \pm 2.5$ GPL U/ml), respectively. Vasculitis, thrombocytopenia and uremia should be considered important factors for the pathogenesis of hemorrhagic disturbances and the main cause of death in severe leptospirosis.
\end{abstract}

KEYWORDS: Leptospirosis; Hemostasis disorders and anticardiolipin antibodies.

\section{INTRODUCTION}

Leptospirosis is a zoonosis caused by microorganisms of the genus Leptospira, which has a worldwide distribution. The Leptospira interrogans complex, of pathogenic nature, contains 23 serogroups and approximately 200 serovars. The disease affects humans, as well as wild and domestic animals, thus constituting one of the most important zoonoses of our environment. In man, pathogenic leptospira can determine various clinical manifestations, from "silent" infections to the icterohemorrhagic form that is also known as Weil's syndrome, which is characterized by the presence of jaundice, followed by a tendency toward hemorrhagic disturbances and acute renal failure (ARF).

The hemorrhagic phenomena present in our environment have been described by several authors ${ }^{2,3,15,19-24}$. PEREIRA DA SILVA et al. ${ }^{24}$ have described hemorrhagic manifestations in $95 \%$ of cases of severe clinical forms of leptospirosis. The following symptoms were reported in the above study, according to decreasing order of frequency: petechiae, epistaxis, hemoptoic expectoration, macroscopic hematuria, ecchymoses, hematemesis, melena, hemoptysis, and bleeding through venous dissection sites. LOMAR et al. ${ }^{16}$, while studying 19 cases of leptospirosis, concluded that pulmonary hemorrhage had been the main cause of death in 15 cases and that massive gastrointestinal bleeding had been the cause in three cases.
JAROONVESAMA et al. ${ }^{14}$, EDWARDS et $a l .{ }^{8}$ and NICODEMO et $a l .{ }^{22}$ have described, in case studies of leptospirosis, alterations in coagulation due to prolonged prothrombin, thrombin and partial thromboplastin times. Low platelet counts, alterations in factor $\mathrm{V}$, alterations in fibrinogen degradation products and of fibrinogen levels are also described.

Bleeding is a common complication in leptospirosis and has become the main cause of death in this disease. Various systematic studies of the alterations in hemostasis have been published ${ }^{7,8,14,19-25}$.

Spirochete-type bacteria, such as those in syphilis, can induce cross reactivity with anticardiolipin antibodies $(\mathrm{ACL})^{18}$. More recently, titers of ACL have been described in patients with Lyme disease and with leptospirosis, both illnesses are caused by spirochetes ${ }^{17}$. The antigenic stimuli responsible for the induction of such antibodies in a spirochete infection and their relationship to the complications of the disease are still relatively unknown.

The ACL is an autoantibody that acts against phospholipids, especially those with a negative charge, and is associated with a syndrome characterized by recurring episodes of arteriovenous thrombosis, thrombocytopenia and repeated miscarriages ${ }^{27}$. These antibodies were

(1) Hospital Universitário Walter Cantídio, Departamento de Medicina Clínica, Faculdade de Medicina, Universidade Federal do Ceará, Fortaleza, CE, Brasil.

(2) Hospital Geral de Fortaleza, Serviço de Nefrologia, Secretaria de Saúde do Estado do Ceará, Fortaleza, CE, Brasil.

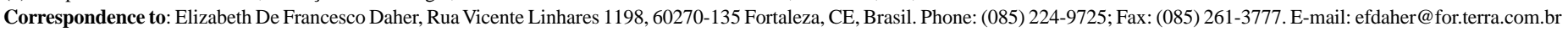


first described in association with cases of systemic lupus erithematosus ${ }^{13,18}$. In the absence of neoplasms and drug use, the condition is denoted as primary antiphospholipid syndrome. The physiopathology of antiphospholipid syndrome is little known.

Thus, the proposal of this study is to evaluate those hemostatic factors related to the hemorrhagic manifestations, as well as the nature and average duration of the bleeding disturbances. The presence of ACL titers in severe forms of leptospirosis will be also determined.

\section{PATIENTS AND METHODS}

Thirty patients with epidemiologic, clinical and laboratory diagnoses of leptospirosis were studied prospectively. All of the patients were male, with ages varying between 16 and 63 years (average of $32 \pm 14$ years). They had severe forms of leptospirosis, with jaundice and acute renal failure, defined as serum creatinine $\geq 1.5 \mathrm{mg} / \mathrm{dL}$. The patients had been admitted to the Walter Cantídio University Hospital of the Faculty of Medicine of the Federal University of Ceará, the São José Hospital of Infectious Diseases and the General Hospital of Fortaleza. They were evaluated on admission, during hospital stay and discharge, thus broaching the acute and convalescence phases of the disease. The study lasted 23 months, from August 1999 to July 2001, with no limit being set as to the number of patients to comprise the study population. Patients that had any other diseases that caused hemorrhagic phenomena, such as hemophilia, chronic liver disease, systemic lupus erythematosus, leukemia, dengue fever, kala-azar, typhoid fever, scurvy, etc, were excluded. All patients included in the study had positive microscopic serum agglutination reactions for leptospirosis, with titers greater than $1: 400$.

Signs and symptoms such as fever, jaundice, myalgia, headaches, vomiting, diarrhea, abdominal pain, reduction of urinary output and dyspnea were registered. The presence and average duration of hemorrhagic manifestations, such as hematemesis, hemoptysis, melena, epistaxis, hemoptoic sputum, hematochezia, hemorrhage in dissection sites, petechiae, ecchymoses, gingival bleeding and hematuria were also recorded.

Three times a week serum levels of urea, creatinine, sodium, potassium, bilirubin, platelets, aminotransferases (AST, ALT), total proteins and fractions, lactate dehydrogenase (LDH), creatine kinase (CK) and total blood cell counts were measured. On admission and discharge the prothrombin time (PT) (reference values: 12.0-14.4 seconds), partial activated thromboplastin time (PATT) (reference values: 32.0-38.4 seconds), thrombin time (TT) (reference values: 9.8-11.0 seconds) and fibrinogen levels (reference values: $150-380 \mathrm{mg} / \mathrm{dl}$ ) were all measured.

During the immune phase, between the $9^{\text {th }}$ and $12^{\text {th }}$ days after onset of symptoms, levels of anticardiolipin antibodies (ACL) were measured by the ELISA kit method (MELISA anticardiolipin IgG and IgM, Walker Diagnostics, Cambridge). Reference values for normal patients were < $10 \mathrm{GLP} \mathrm{U} / \mathrm{ml}$ for IgG and $<7 \mathrm{MLP} \mathrm{U} / \mathrm{ml}$ for $\operatorname{IgM}^{28}$. During hospital stay, occurrence of dialysis, as well as the type performed (hemodialysis or peritoneal dialysis), presence of hemorrhagic manifestations and occurrence of death were also recorded.
Anticardiolipin antibody levels were analyzed in the sera of nine patients with various infectious diseases except leptospirosis (control group), during the acute phase of each disease. Five of the patients were female and 4 were male, the average age being $35 \pm 10$ years. Two of the patients had kala-azar, 2 had tetanus, 2 had septicemia caused by Staphylococcus aureus, 1 had dengue fever, 1 had type A hepatitis, and 1 had meningococcemia. The diagnoses of all of these patients' respective diseases were confirmed through laboratory exams (serology, agent isolation, etc.), with the exception of the patients with tetanus, which diagnosis was made through the clinical history and physical examination. All of the members of the control group were in-patients in the São José Hospital of Infectious Diseases.

The study protocol was approved by the Ethics Committee of the Walter Cantídio University Hospital, Faculty of Medicine, Federal University of Ceará. All patients gave informed consent.

For statistical analysis of the results, the Student $t$ test was used in order to verify variations between laboratory values on admission versus discharge and ACL titers of the patients with leptospirosis versus control group. Results were expressed as mean \pm SD and were considered significant when descriptive levels were less than $5 \%$ or $p<0.05$.

\section{RESULTS}

The main signs and symptoms upon admission excluding hemorrhagic manifestations were fever, jaundice and myalgia in 100\% of the cases; vomiting, diarrhea, headaches, decreased urinary output and abdominal pain in $30 \%$; and dyspnea in $10 \%$.

The duration of hospital stay was $12 \pm 9$ days, and the time elapsed until occurrence of hemorrhagic manifestations was $9 \pm 4$ days after onset of the clinical course. A total of 26 of the 30 patients $(86 \%)$ presented with some form of bleeding during hospital stay; of these, 17 (56\%) exhibited more than one form of bleeding. The hemorrhagic phenomena observed were: hemoptysis in 12 patients, conjunctival bleeding in 9 , macroscopic hematuria in 7 , melena in 6 , epistaxis in 6 , hematemesis in 6 , petechiae in 3 , gingival bleeding in 1 , hematochezia in 1 and bleeding from venous dissection sites in 1 patient.

There were a significant decline in hematocrit and hemoglobin levels during hospital stay due to the hemorrhagic disturbances. Patient serum levels of urea and creatinine upon admission were elevated, yet, by the time of discharge, there had been a significant reduction $(\mathrm{p}<0.05)$, indicating recovery of renal function (Table 1). On admission, total bilirubin levels were $23 \pm 14 \mathrm{mg} / \mathrm{dl}$, albumin levels were $2.4 \pm 0.3 \mathrm{~g} / \mathrm{dl}$, CK levels were $445 \pm 690 \mathrm{U} / \mathrm{ml}$, LDH levels were $764 \pm 334 \mathrm{U} / \mathrm{ml}$, AST levels were $135 \pm 89 \mathrm{U} / \mathrm{ml}$ and ALT levels were $95 \pm 73 \mathrm{U} / \mathrm{ml}$.

Prothrombin time on admission was significantly prolonged and fibrinogen levels were significantly elevated compared to those upon discharge. PATT and TT during admission were unaltered compared to discharge values (Table 1).

Platelet counts were fairly low on admission, but by the time of discharge, they had returned to normal (Table1). Only two patients had platelets levels that were above $150,000 / \mathrm{mm}^{3}$ at the time of admission 
Table 1

Admission and discharge laboratory data of patients with leptospirosis

\begin{tabular}{|c|c|c|c|}
\hline & $\begin{array}{c}\text { ADMISSION } \\
\mathrm{n}=30\end{array}$ & $\begin{array}{c}\text { DISCHARGE } \\
\quad \# \mathrm{n}=27\end{array}$ & $\mathrm{p}$ \\
\hline Hematocrit (\%) & $33 \pm 5^{*}$ & $27 \pm 6$ & 0.0001 \\
\hline Hemoglobin $(\mathrm{g} / \mathrm{dl})$ & $11 \pm 2 *$ & $9 \pm 2$ & 0.007 \\
\hline Urea $(\mathrm{mg} / \mathrm{dl})$ & $182 \pm 95^{*}$ & $67 \pm 31$ & 0.0004 \\
\hline Creatinine (mg/dl) & $5.7 \pm 3.4^{*}$ & $1.6 \pm 1.0$ & 0.0009 \\
\hline Prothrombin Time (seconds) & $13.3 \pm 0.8^{*}$ & $12.8 \pm 0.8$ & 0.025 \\
\hline Activated Partial Thromboplastin Time (seconds) & $32.7 \pm 2.1$ & $33.1 \pm 2.8$ & 0.530 \\
\hline Thrombin Time (seconds) & $11.0 \pm 1.4$ & $10.8 \pm 1.5$ & 0.110 \\
\hline Fibrinogen $(\mathrm{mg} / \mathrm{dl})$ & $515 \pm 220 *$ & $322 \pm 95$ & $<0.0001$ \\
\hline Platelets $\left(\mathrm{x}^{3} 0^{3} / \mathrm{mm}^{3}\right)$ & $69 \pm 65^{*}$ & $280 \pm 181$ & $<0.0001$ \\
\hline
\end{tabular}

Significant $* \mathrm{p}<0.05$ versus discharge. \# $(\mathrm{n}=27)$ three patients died.

and four patients presented with counts lower than $150,000 / \mathrm{mm}^{3}$ upon discharge (with the exception of the 3 patients that had died).

Measurement of the IgM and IgG fractions of ACL levels in 28 of the 30 patients revealed that 18 patients $(64.2 \%)$ had levels considered reactive for the IgM fraction of this type of antibody, at $28.5 \pm 32.4 \mathrm{MPL} \mathrm{U} / \mathrm{ml}$. Twenty-two patients (78.5\%) had reactive levels for the $\mathrm{IgG}$ fraction with counts of $36.7 \pm 36.1 \mathrm{GPL} \mathrm{U} / \mathrm{ml}$. Levels of ACL in the 9 patients of the control group were 11.5 \pm 7.9 MPL U/ml for the IgM fraction and $6.5 \pm$ $2.5 \mathrm{GPL} \mathrm{U} / \mathrm{ml}$ for the $\mathrm{IgG}$ fraction. ACL titers between the patients with leptospirosis and those of the control group were significantly different ( $\mathrm{p}$ $<0.05$ ) for both the IgM and IgG fractions (Fig. 1 and 2).

Regarding the need for dialysis, 19 (63\%) patients underwent dialysis due to onset of acute renal insufficiency that was non-responsive to hydration. Of these, 13 underwent peritoneal dialysis and 6 had continuous slow hemodialysis.

\section{IgM ANTICARDIOLIPIN ANTIBODY}

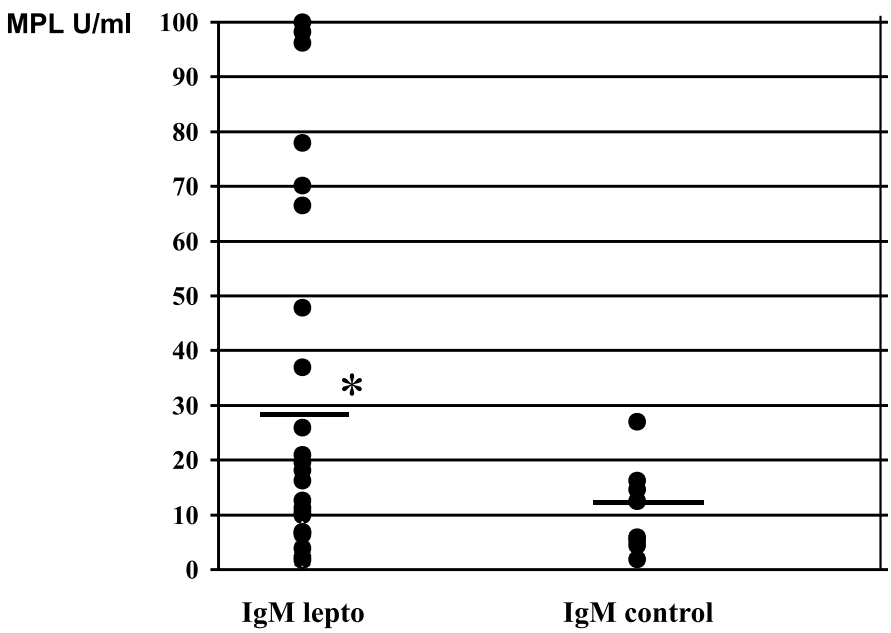

Fig. 1- IgM anticardiolipin antibody titers in leptospirosis and control. * $\mathrm{p}<0.05$ vs control.
Three patients died. One patient developed massive pulmonary hemorrhage, another suffered bleeding from various sites (hemoptysis, hematemesis, and bleeding from a venous dissection site) and the third developed a rapid decline in consciousness, with eventual coma and anisocoria, suggesting central nervous system hemorrhage.

\section{DISCUSSION}

Analysis of the study population revealed that the group consisted primarily of young adults, all of the male sex. The absolute participation of male patients can be explained by examination of some patients' occupations, as leptospirosis is a disease with an important epidemiological-occupational component involved in its transmission ${ }^{1,11,30}$. On the other hand, in our environment, this illness has a global distribution that is independent of occupation, as all patients had described the main transmitters (rats) as present in their surroundings.

\section{IgG ANTICARDIOLIPIN ANTIBODY}

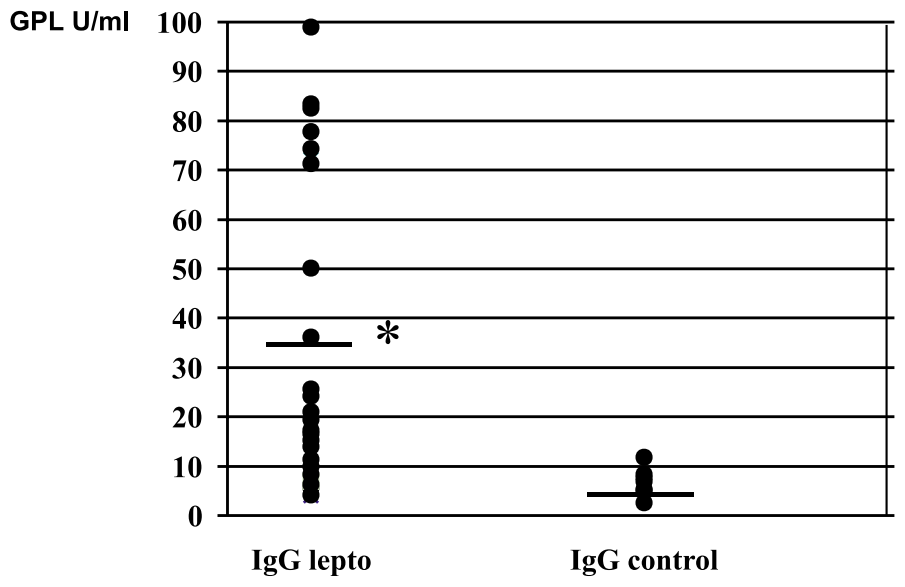

Fig. 2- IgG anticardiolipin antibody titers in leptospirosis and control. *p $<0.05$ vs control 
In the current study, the majority of patients with severe forms of leptospirosis presented with some type of alteration in hemostasis with subsequent hemorrhagic manifestations that occurred, on average, after the first week of symptom onset; this period began on the ninth day and corresponds to the beginning of the immunological phase of the disease. The complication most frequently found was of pulmonary nature with clinical manifestation in the form of hemoptysis, thus revealing the recent presentation, in our midst, of pulmonary complaints associated with severe forms of leptospirosis , $^{1,2,3,5,10}$.

Hemostasis consists of three main elements: coagulation factors, platelets, and blood vessels. Typically, PT is altered when changes or deficiencies are present in coagulation factors dependent on vitamin $\mathrm{K}$, such as factors II, VII and X, and in C and S proteins. In the present study a statistically significant variation in PT upon admission was observed compared to that upon discharge. The significant increase in bilirubin level and slight elevation in transaminase level observed during the acute phase suggest hepatic cholestasis that had led to a vitamin $\mathrm{K}$ deficiency and to an eventual increase in prothrombin time ${ }^{4}$.

It is known that TT is influenced by three factors: decreased fibrinogen levels, increase in fibrinogen/fibrin degradation products and administration of heparin. In the present study, on average, TT did not suffer elevation, which is corroborated by the fibrinogen levels found.

Deficiencies in the intrinsic factors of coagulation (factors VIIIc, IX, X, XI and XII) and administration of heparin are the main elements responsible for increased PATT. In the current study no important changes or statistically significant alterations were found between the PATT levels on admission and discharge, which allows for the supposition that intrinsic coagulation factors are not significantly altered in human leptospirosis, thus remaining uninvolved in the genesis of hemorrhagic disturbances.

Fibrinogen is produced by the liver and by cells within the endothelial reticulum system. The plasmatic concentration of fibrinogen may increase up to 2.5 times after inflammatory stimuli and can remain elevated during several weeks. In the present study a significant increase in fibrinogen was seen, which can be considered a consequence of the inflammatory reaction that occurs in leptospirosis. HIGGINS \& COUSINEAU ${ }^{12}$ interpreted the resulting fibrinogen elevation and hemorrhagic disturbances in guinea pigs infected with leptospirosis as being a result of the increased fibrinogen production by the liver in response to increased consumption. On the other hand, SITPRIJA et al. ${ }^{29}$ attributed this increase to the phenomenon of vascular endothelial lesions caused by the leptospira.

In our study, platelet counts were found to be significantly lower upon admission than at time of discharge, with the admission levels of platelets reduced to values that were much lower than normal, at levels compatible with the appearance of hemorrhagic manifestations. This seems to be the part of coagulation most affected in the severe forms of leptospirosis. Such findings are in accordance with those observed by several authors ${ }^{7,15,19-23}$. NICODEMO et al. ${ }^{22}$ observed that thrombocytopenia in leptospirosis seems to be determined by activation, adhesion and aggregation of platelets to the stimulated vascular endothelium by the action of endotoxin or other bacterial products. Adhesion may be mediated by platelets surface receptors that have a high affinity for adhesion glycoproteins detected in the subendothelium. The same authors identified in vascular lung fragments of the patients with severe leptospirosis a formation of an amorphous electron-dense substance, between the endothelial cells and adherent platelets, that could be von Willenbrand factor or other endothelium adhesion protein. This would lead subsequent adhesion of platelets in those places where the subendothelial collagen was not exposed and the presence of fibrin in the platelets aggregates was not observed.

Disseminated intravascular coagulation is an epiphenomenon that involves the following laboratory alterations: reduced platelet counts; prolonged TT, PT, and PATT; and normal or reduced fibrinogen. Only PT prolongation and thrombocytopenia were seen in the present study. From this information, it can be seen that disseminated intravascular coagulation does not habitually occur in human leptospirosis. This finding corroborate with literature data ${ }^{15,21,22}$.

Nineteen of the 30 patients, in this study, required dialytic treatment during hospital stay, thus revealing the elevated percentage of severe leptospirosis with acute renal failure unresponsive to clinical treatment with hydration and diuretic use. The dialytic indication was due to uremia and/or volume overload.

In the current study, it was seen that serum urea was highly elevated in patients with severe leptospirosis and hemorrhages, indicating that uremia might contribute to the severity of the bleeding disturbances in leptospirosis. Uremic bleeding appears to correlate most closely with prolongation of bleeding time, due primarily to platelet dysfunction ${ }^{6,9}$.

Regarding analysis for ACL in the sera of the patients studied, the majority was found to be positive for $\operatorname{IgM}$ and $\operatorname{IgG}$ with considerably elevated titers $(\geq 50 \mathrm{mpl} / \mathrm{gpl})$ for such antibodies, thus corroborating their involvement in the severe manifestations of leptospirosis. ACL dosage in our control group did not display reactive levels of IgG, and IgM was present in low titers. Statistically significant difference was observed between titers of both fractions when compared to those of the patients with leptospirosis. Thus, it can be seen that there is no significant increase in the presence of these antibodies in infectious diseases other than leptospirosis. The nature of the pathological findings in leptospirosis for vascular lesions (vasculitis) and hemorrhage is probably due to cytotoxic and immunologic mechanisms ${ }^{28}$. The presence of ACL in leptospirosis suggests that these antibodies can induce cross reactivity with vascular endothelial cells and with other cell membranes, contributing perhaps to the physiopathologic mechanisms of the severe form of this disease, among these being the hemorrhagic disturbances ${ }^{28}$.

Regarding mortality, in our study, was observed that in all of the cases bleeding was implicated as a possible cause. This is in agreement with the data in the scientific literature which describe bleeding as the main cause of death in leptospirosis ${ }^{10,16,25}$.

In conclusion, the hemorrhagic manifestations occurred after one week following symptoms onset. The coagulation disorders revealed no disseminated intravascular coagulation in the severe leptospirosis. Thrombocytopenia in the acute phase of the illness plays a role in the hemorrhagic disturbances. ACL assay showed that the majority of patients had reactive titers for the $\operatorname{IgM}$ and $\mathrm{IgG}$ fractions in the severe form of leptospirosis. Uremia is a factor that also contributes to bleeding in the 
acute phase of disease. The hemorrhagic disturbances represent the main cause of death.

\section{RESUMO}

Avaliação das alterações da hemostasia e anticorpo anticardiolipina em pacientes com a forma grave da leptospirose

Foram avaliados prospectivamente os fatores envolvidos nas alterações da hemostasia e níveis de anticorpo anticardiolipina em 30 pacientes com a forma grave da leptospirose e insuficiência renal aguda (IRA) (IRA foi definida como creatinina sérica $\geq 1,5 \mathrm{mg} / \mathrm{dl}$ ). Os pacientes foram internados no Hospital Universitário Walter Cantídio, Hospital São José de Doenças Infecciosas e Hospital Geral de Fortaleza, Ceará, de agosto/1999 a julho/ 2001. Todos eram do sexo masculino com idade de $32 \pm 14$ anos e apresentavam manifestações clínicas com diagnóstico laboratorial de leptospirose associada à IRA. O tempo do início dos sintomas ao aparecimento das manifestações hemorrágicas foi de $9 \pm 4$ dias. As manifestações hemorrágicas foram observadas em $86 \%$ dos pacientes. Dados laboratoriais mostraram níveis significativamente elevados de uréia, $181 \pm 95 \mathrm{mg} / \mathrm{dl}$; fibrinogênio, $515 \pm 220 \mathrm{mg} / \mathrm{dl}$; tempo ativado de protrombina, 13,3 $\pm 0,9 \mathrm{seg}$ e diminuição das plaquetas, $69 \pm 65 \times 10^{3} / \mathrm{mm}^{3}$ na admissão. Não houve alteração no tempo de trombina e de tromboplastina parcial ativado. Os níveis de ACL IgG e IgM estavam significativamente elevados $(\mathrm{p}<0,05)$ na forma grave da leptospirose quando comparados ao grupo controle (28,5 $\pm 32,4$ vs. $11,5 \pm 7,9 \mathrm{MPL}$ U/ $\mathrm{ml}$ e $36,7 \pm 36,1$ vs. $6,5 \pm 2,5 \mathrm{GPL} \mathrm{U} / \mathrm{ml}$ ), respectivamente. A vasculite, trombocitopenia e uremia devem ser consideradas como fatores importantes na patogênese dos distúrbios hemorrágicos observados na forma grave da leptospirose que constituem a principal causa de óbito na doença.

\section{ACKNOWLEDGMENTS}

We wish to thanks our colleagues, residents and nurses from Walter Cantídio University Hospital, Faculty of Medicine, Federal University of Ceará (UFC), General Hospital of Fortaleza (HGF), São José Hospital of Infectious Diseases and the Nephrology Institute of Ceará (INECE) for the assistance provided to patients. We also would like to extend our thanks to the Public Central Laboratory of Ceará (LACEN), the Center for Hemotherapy of Ceará (HEMOCE) and the Clinical Pathology Institute under the supervision of Prof. Dr. Emir Lima Verde.

\section{REFERENCES}

1. CORREA, M.O.A.; VERONESI, R.; BRITO, T. et al. - Leptospirose. In: VERONESI, R. Doenças infecciosas e parasitárias. 7. ed. Rio de Janeiro, Guanabara Koogan, 1982. p. 573-592.

2. DAHER, E.F.; ZANETTA, D.M.T.; CAVALCANTE, M.B. \& ABDULKADER, R.C. Risk factors for death and changing patterns in leptospirosis acute renal failure. Amer. J. trop. Med. Hyg., 61: 630-634, 1999.

3. DAHER, E.F. - Avaliação da função renal a longo prazo em pacientes com insuficiência renal aguda associada à leptospirose. São Paulo, 1999. (Tese de Doutorado Faculdade de Medicina da Universidade de São Paulo).

4. DE BRITO, T. - On the pathogenesis of hepatic and renal lesions in leptospirosis. Rev. Inst. Med. trop. S. Paulo, 10: 238-241,1968.
5. DUPONT, H.; DUPONT-PERDRIZET, D.; PIERIE, J.L. et al. - Leptospirosis: prognostic factors associated with mortality. Clin. infect. Dis., 25: 720-724, 1997.

6. EBERST, M.E. \& BERKOWITZ, L.R. - Hemostasis in renal disease: pathophysiology and management. Amer. J. Med., 96: 168-179, 1994.

7. EDWARDS, C.N.; NICHOLSON, G.D. \& EVERARD, C.O.R. - Thrombocytopenia in leptospirosis. Amer. J. trop. Med. Hyg., 31: 827-829, 1982.

8. EDWARDS, C.N.; NICHOLSON, G.D.; HASSELL, T.A.; EVERARD, C.O.R. \& CALLENDER, J. - Thrombocytopenia in leptospirosis: the absence of evidence for disseminated intravascular coagulation. Amer. J. trop. Med. Hyg., 35: 352-354, 1986.

9. ESCOLAR, G.; CASES, A.; BASTIDA, E. et al. - Uremic platelets have a functional defect affecting the interaction of von Willebrand factor with glycoprotein IIb-IIIa. Blood, 76: 1336-1340, 1990 .

10. GONÇALVES, A.J.R.; CARVALHO, J.E.M.; SILVA, J.B.G.; ROZEMBAUM, R. \& VIEIRA, A.R.M. - Hemoptise e síndrome de angústia respiratória do adulto como causa de morte na leptospirose. Mudanças de padrão clínicos e anatomopatológicos. Rev. Soc. bras. Med. trop., 25: 261-270, 1992.

11. HEATH Jr., C.W.; ALEXANDER, A.D. \& GALTON, M.M. - Leptospirosis in the United States. New Engl. J. Med., 273: 857-864, 1965.

12. HIGGINS, R. \& COUSINEAU, G. - The pathogenesis of leptospirosis. I. Hemorrhages in experimental leptospirosis in guinea pigs. Canad. J. comp. Med., 41: 174-181, 1977.

13. HUGHES, G.R.V. - Thrombosis, abortion, cerebral disease, and the lupus anticoagulant. Brit. med. J., 287: 1088-1089, 1983.

14. JAROONVESAMA, N.; VIRANUVATTI, V. \& CHAROENLARP, K. - Coagulation studies in leptospirosis. Southeast Asian J. trop. Med. publ. Hlth., 6: 562-566, 1975.

15. LOMAR, A.V. - Leptospirose. Estudo das alterações da hemostasia na leptospirose. São Paulo, 1989. (Dissertação de Mestrado - Faculdade de Medicina da Universidade de São Paulo).

16. LOMAR, A.V.; ARAUJO, M.F.; LANCELLOTTI, C.L.P. et al. - Estudo da "causa mortis" em 19 casos de leptospirose na U.T.I. do Hospital "Emilio Ribas”. In: CONGRESSO BRASILEIRO DE INFECTOLOGIA, 2., São Paulo, 1983. Resumos. p. 54.

17. MACKWORTH-YOUNG, C.G.; HARRIS, E.N.; STEERE, A.C. et al. - Anticardiolipin antibodies in Lyme disease. Arthr. and Rheum., 31: 1052, 1988.

18. MATSUURA, E.; IGARASHI, Y.; FUJIMOTO, M.; ICHIKAWA, K. \& KOIKET, T. Anticardiolipin cofactor and differential diagnosis of autoimmune disease. Lancet, 2: $177-178,1990$.

19. NICODEMO, A.C. - Contribuição ao estudo da plaquetopenia na leptospirose. São Paulo, 1987. (Dissertação de Mestrado - Faculdade de Medicina da Universidade de São Paulo).

20. NICODEMO, A.C. - Análise de aspectos microscópicos, imuno-histoquímicos e ultraestruturais do pulmão na leptospirose para a compreensão da patogenia da plaquetopenia. São Paulo, 1993. (Tese de Doutorado - Faculdade de Medicina da Universidade de São Paulo).

21. NICODEMO, A.C.; DEL NEGRO, G. \& AMATO NETO, V. - Thrombocytopenia and leptospirosis. Rev. Inst. Med. trop. S. Paulo, 32: 252-259, 1990.

22. NICODEMO, A.C.; DUARTE, M.I.S.; ALVES,V.A.F. et al. - Lung lesions in human leptospirosis: microscopic, immunohistochemical, and ultrastructural features related to thrombocytopenia. Amer. J. trop. Med. Hyg., 56: 181-187, 1997.

23. NICODEMO, A.C.; MEDEIROS, N.; DEL NEGRO, G. \& AMATO NETO, V. - Alterações hematológicas na leptospirose. Rev. Inst. Med. trop. S. Paulo, 31: 71-79, 1989. 
DAHER, E.F.; OLIVEIRA NETO, F.H. \& RAMIREZ, S.M.P. - Evaluation of hemostasis disorders and anticardiolipin antibody in patients with severe leptospirosis. Rev. Inst. Med. trop. S. Paulo, 44(2):85-90, 2002.

24. PEREIRA DA SILVA, J.J.; PAIVA, L.M.; SOUZA NETTO, B.A.; GUEDES E SILVA, J.B. \& COURA, J.R. - Estudo preliminar das leptospiroses no Estado do Rio de Janeiro. Rev. Soc. bras. Med. trop., 2: 317-337, 1968

25. RAMACHANDRAN, S. \& PERERA, M.V.F. - Cardiac and pulmonary involvement in leptospirosis. Trans. roy. Soc. trop. Med. Hyg., 71: 56-59, 1977.

26. RAOULT, D.; JEANDEL, P.; MAILLOUX, M. \& ROUGIER, Y. - Thrombocytopenia and renal failure in leptospirosis. Amer. J. trop. Med. Hyg., 32: 1464, 1983.

27. ROUBEY, R.A.S. \& HOFFMAN, M. - From antiphospholipid syndrome to antibodymediated thrombosis. Lancet, 350: 1491-1493, 1997.
28. RUGMAN, F.P.; PINN, G.; PALMER, M.F.; WAITE, M. \& HAY, C.R.M. - Anticardiolipin antibodies in leptospirosis. J. clin. Path., 44: 517-519, 1991.

29. SITPRIJA, V.; PIPATANAGUL, V.; MERTOWIDJOJO, K.; BOONPUCKNAVIG, V. \& BOONPUCKNAVIG, S. - Pathogenesis of renal disease in leptospirosis: clinical and experimental studies. Kidney Int., 17: 827-836,1980.

30. VINETZ, J.M. - Leptospirosis. Curr. Opin. infect. Dis., 14: 527-538, 2001.

Received: 28 November 2001

Accepted: 18 February 2002 